\title{
SIGILO BANCÁRIO: O JUIZ E A GUARDA DA PRIVACIDADE DO CIDADÃO NA SOCIEDADE DA INFORMAÇÃO
}

\section{Bruno Batista da Costa de Oliveira ${ }^{1}$ Marco Antonio Barbosa ${ }^{2}$}

\section{Resumo}

O tema é a quebra do sigilo bancário no âmbito do processo judicial brasileiro. O objetivo é analisar criticamente os principais argumentos invocados para a mitigação, pelos juízes, de um dos aspectos do direito fundamental à privacidade, tido como inviolável pelo ordenamento constitucional. O método é a análise do discurso, de matiz foucaultiana, procedendo-se a genealogia dos enunciados doutrinários, jurisprudenciais e legais, relativos a esta inviolabilidade e aos atributos conferidos no plano simbólico aos juízes, por meio da personificação do ato decisório, sustentada, acriticamente, em supostas virtudes dos magistrados. Conclui-se que os discursos analisados, além de objetivamente resultarem em ausência de controle dos critérios ou fundamentos das decisões judiciais, estabelecem uma relação disciplinar que sublima a figura do magistrado, tornando-o a encarnação monocrática da autoridade do Estado, em potencial prejuízo às garantias fundamentais do cidadão.

Palavras-chave: privacidade; sigilo bancário; interesse público; jurisdição; análise de discursos.

\section{INTRODUÇÃO}

A privacidade, a exemplo de outros direitos fundamentais previstos no rol do artigo $5^{\circ}$ da Constituição Federal, é descrita como inviolável. No entanto, a prática forense, confirmada pela interpretação dominante dos tribunais superiores, demonstra que, desde que observados certos requisitos, a prometida inviolabilidade deve

\footnotetext{
${ }^{1}$ Mestre (2011) e Doutor (2014) em Teoria Geral do Estado pela Faculdade de Direito da Universidade de São Paulo. Professor de Direito Constitucional da Universidade de Mogi das Cruzes em São Paulo, Estado de São Paulo, Brasil. Advogado em São Paulo.E-mail:bbcoliveira@hotmail.com

${ }^{2}$ Mestre (1993) e Doutor (1999) em Teoria Geral do Estado pela Faculdade de Direito da Universidade de São Paulo. Consultor do Uniceub, Centro Universitário de Brasília. E-mail: mantobarbosa@gmail.com
} 
sucumbir: a chamada quebra do sigilo, por ordem judicial, acontece rotineiramente, sem delongas e automaticamente $^{3}$, seguindo um singelo protocolo procedimental, que no mais das vezes passa quase despercebido.

Este estudo visa avaliar os simbolismos que envolvem o mandato outorgado aos juízes que lhes autoriza a, mitigando a garantia de inviolabilidade da privacidade, determinar a quebra do sigilo bancário. $\mathrm{O}$ método empregado será a análise de discursos foucaultiana, por meio da qual se busca entender, a partir da observação de enunciados que permeiam a atividade jurisdicional, a racionalidade de que se reveste o poder atribuído aos magistrados para quebrar sigilos bancários. Esta metodologia parte, em síntese, do pressuposto de que o poder político na contemporaneidade se exerce no plano simbólico, por meio de um conjunto de enunciados destinados a formatar uma determinada visão idealizada da realidade. Ao fazê-lo, tais enunciados - que em conjunto configuram determinados discursos - agem de modo disciplinador ao moldar as atitudes dos sujeitos por eles atingidos; o poder, entendido então como meio de controle social, atua de forma difusa, ou, como diria Michel Foucault, "transita pelos indivíduos" (FOUCAULT, 1997, p. 26). Vale dizer, para esta corrente de pensamento, os comandos manifestados discursivamente são espalhados pelos membros da coletividade: o poder disciplinar do discurso é o que permite convencer alguém a fazer ou não algo, não porque coagido, mas porque aquilo seria a conduta esperada. Assim é que a forma de produção e difusão dos enunciados discursivos é elemento determinante da predominância de certa ideologia e, por essa razão, a sua produção é, nas palavras de Michel Foucault "controlada, selecionada, organizada e redistribuída por um certo número de procedimentos" com o objetivo de consolidar a prevalência do discurso desejado ou, ainda de acordo com o filósofo francês, "conjurar os seus poderes e perigos, dominar o evento aleatório, esquivando a sua pesada e temível materialidade" (FOUCAULT, 1971, p. 10-11). Por meio do emprego desse método objetiva-se acessar os elementos simbólicos que compóem o discurso da autoridade e trazer à tona os mecanismos semânticos, os jogos de linguagem que permitem definir certo imaginário simbólico e, a partir daí, agir socialmente na disciplina dos sujeitos do discurso.

Este estudo não propõe a defesa da inviolabilidade do sigilo bancário, como se os dados patrimoniais dos indivíduos devessem ser protegidos por barreiras insuperáveis. Ao contrário. Dado que os limites dessa inviolabilidade existem, o foco é encontrar as motivações para a permissão dada, e a quem ela é dada, para transpôlos. Assim, pouco importa saber se a figura escolhida - a saber, o juiz - é a figura mais indicada a decretar a quebra

\footnotetext{
${ }^{3} \mathrm{O}$ Poder Judiciário dispõe de uma ferramenta digital que permite consultas automáticas a dados bancários de qualquer cidadão, $\mathrm{o}$ Bacen Jud; de acordo com as informações disponibilizadas pela Autarquia na internet: "O Bacen Jud é um instrumento de comunicação eletrônica entre o Poder Judiciário e instituições financeiras bancárias, com intermediação, gestão técnica e serviço de suporte a cargo do Banco Central. Por meio desse sistema, os magistrados protocolizam ordens judiciais de requisição de informações, bloqueio, desbloqueio e transferência de valores bloqueados, que são transmitidas às instituições bancárias para cumprimento e resposta." Cfr. http://www.bcb.gov.br/fis/pedjud/asp/servicos_poder_judiciario/introducao.asp, acesso em $4 / 6 / 17$.
} 
do sigilo, ou ainda os critérios normativos adotados para fazê-lo. Interessa entender o apanágio simbólico de que o juiz foi revestido para desprezar a inviolabilidade do direito ao sigilo, no bojo de uma teoria de direitos fundamentais autodeclarada garantista, isto é, pautada - em tese - pela tutela do cidadão contra intervenções do Estado em sua vida privada. A garantia da inviolabilidade da vida privada é, pois, o pano de fundo deste estudo que se dedica a avaliar um aspecto relevante - mas pouco explorado - da tutela desse direito, a saber: qual discurso, e como ele atua para moldar a atuação dos juízes no contexto específico da mitigação de direitos fundamentais, neste caso, o da privacidade?

Para tanto, apresentam-se em um primeiro momento algumas impressões a respeito da privacidade e do sigilo bancário, para depois explorar o mote justificador da mitigação da sua inviolabilidade, a saber, o que se convencionou chamar interesse público. Após, são avaliados os limites (ou a ausência deles) estabelecidos para determinar os parâmetros definidores desse interesse público, finalizando com a análise dos elementos simbólicos que cercam a figura do magistrado, com o objetivo de legitimar o seu poder de determinar a quebra do sigilo bancário.

\section{A TUTELA JURÍDICO-CONSTITUCIONAL DA PRIVACIDADE}

As referências doutrinárias mais comuns às origens da proteção à privacidade remetem à dicotomia existente na Antiguidade greco-romana entre as questões atinentes à vida familiar do cidadão e aquelas que seriam de interesse da polis ou da coisa pública, passam pela materialização do seu objeto, realizada pela ideologia burguesa liberal preocupada em manter todos os aspectos de sua individualidade (sobretudo o patrimônio) a salvo de achaques de monarcas autoritários, para em uma fase posterior colocar o acento sobre sua condição de direito fundamental necessário à preservação dos diversos modos de ser do cidadão nas sociedades pós-modernas (CANCELlier DE OLIVO e CANCELLIER DE OLIVO, 2016 e RUARO e LIMBERGER, 2011). Encontram-se também menções aos desafios da proteção à privacidade em face do desenvolvimento e da digitalização das comunicações e das relações sociais, sustentando-se que o eixo da proteção jurídica se teria desviado da manutenção do segredo para se "assegurar o controle do fluxo dessas informações" (GEDIEL e CORRÊA, 2008). Em síntese, a tutela jurídica da privacidade nos sistemas jurídicos ocidentais seria, segundo esta narrativa, o fruto de uma evolução contínua ao longo da qual a sua inviolabilidade teria sido o fio condutor, embora os elementos que a integraram nem sempre teriam sido os mesmos (família-patrimônio-intimidade, a grosso modo).

Essa descrição do direito à privacidade e de sua mutação ao longo dos anos, independentemente de sua correção, contém alguns enunciados-chave que interessam à presente análise, porque estão imbuídos de 
simbolismos que formataram um imaginário (habitus, segundo Pierre Bourdieu ${ }^{4}$ ) a respeito do direito à privacidade, os quais, tomados em conjunto, contribuem para a consolidação de um discurso.

Um dos elementos simbólicos que sobressaem nesta narrativa é a equiparação da privacidade a um patrimônio do cidadão (GEDIEL e CORRÊA, 2008, p. 142). Por mais que os ordenamentos constitucional e legal brasileiros destaquem o seu caráter inviolável e irrenunciável (CF, art. $5^{\circ}$, inc. X e CC, art. 11), as referências mais comuns à tutela à privacidade remetem à mesma proteção conferida pelo sistema jurídico a um bem, ainda que ele seja imaterial.

Nesse sentido, não bastasse o fato de a tutela da privacidade ser em grande parte disciplinada no plano infraconstitucional pelo Código Civil - o campo do direito privado por excelência -, um claro sintoma dessa materialização é a precificação da sua violação ilícita: o sistema legal não dispõe de efetivos mecanismos para que a sua infringência seja evitada, propondo apenas que ela seja reparada pela via indenizatória. O inciso X do artigo $5^{\circ}$ da Constituição Federal prevê que o descumprimento das obrigações de preservação da vida privada implica no "direito a indenização pelo dano material ou moral decorrente de sua violação", e o artigo 12 do Código Civil assegura à vítima de violação o direito de "reclamar perdas e danos". Não se ignora que o mesmo Código Civil menciona a possibilidade de fazer cessar "a ameaça, ou a lesão" aos direitos da personalidade (art. 12), bem como que "o juiz, a requerimento do interessado, adotará as providências necessárias para impedir ou fazer cessar ato contrário" à inviolabilidade da privacidade (art. 21), mas essas medidas raramente são tomadas, eis que oprimidas pela simbologia da censura da qual foram revestidas 6 .

Outra evidência da materialização da privacidade se revela no fenômeno, bem próprio da contemporaneidade, de os próprios titulares do direito deliberadamente exporem diversos aspectos de sua privacidade seja nas chamadas mídias sociais virtuais, ou ainda nos seus relacionamentos com prestadores de serviços de consumo ${ }^{7}$. A questão que importa aqui não é tanto a prerrogativa de as pessoas disporem de sua

\footnotetext{
${ }^{4} \mathrm{O}$ conceito de habitus desenvolvido pelo sociólogo francês Pierre Bourdieu, é definido por Soraya Nour Sckell como "um sistema de esquemas adquiridos que funcionam como categorias de percepção e apreciação, classificação e organização da ação" o qual gera "uma estrutura mental ou cognitiva que internaliza a ordem social". Assim é que o "habitus gera (de modo não mecânico) os comportamentos que são apropriados para a lógica objetiva do campo social.” (SCKELL, 2016, p. 160).

${ }^{5}$ É o que se lê na doutrina constitucional, quando ela analisa o citado inciso X do artigo $5^{\circ}$. José Adércio Leite Sampaio, por exemplo, afirma que: "A violação do direito à vida privada, à intimidade, à honra e à imagem dá ensejo à pretensão indenizatória por danos materiais e morais. Danos materiais são lesões a interesses pecuniários de uma pessoa ou que levem à diminuição, perda ou deterioração do potencial de exploração econômica de alguns dos aspectos dos direitos protegidos pelo inciso X." (SAMPAIO, 2013, p. 284).

${ }^{6}$ Nesta senda, confira-se: "A autoridade judiciária há de precatar-se no deferimento de tais tutelas diante da possibilidade de converter-se num ilegítimo censor ao avançar perigosamente sobre domínios próprios da vida democrática." (SAMPAIO, 2013, p. 285).

${ }^{7}$ A propósito, a opinião de Luis Carlos Cancellier de Olivo e Mikhail Vieira Cancelier de Olivo: "Nesse sentido, é facilmente notável que a área da privacidade acabou transformando-se num lugar de encarceramento, 'sendo o dono do espaço privado condenado e sentenciado a padecer expiando os próprios erros', o que nos leva à conclusão de que, hoje, a relação entre o indivíduo
} 
privacidade em atenção a um desejo de expiação pública, mas a forma como esse tema é discutido pelos juristas, e deste modo integra-se aos seus habitus: quando se lê que, em razão dessa prática, o direito tem buscado criar mecanismos que assegurem ao titular de dados privativos o "controle não só sobre o acesso, mas também no que se refere ao seu tratamento, à sua utilização e à sua circulação" (GEDIEL e CORRÊA, 2008, pp. 142-143), se é diretamente remetido à simbologia dos direitos reais, que recaem sobre coisas (res). Com efeito, é próprio dos direitos reais o chamado direito de sequela, que assegura ao seu titular a prerrogativa "de seguir a coisa nas mãos de quem quer que a detenha, de apreendê-la para sobre ela exercer seu direito real” (RODRIGUES, 2009, p. 7). Por outras palavras, a exemplo do proprietário de algo, a quem se assegura a prerrogativa de perseguir e retomá-lo de qualquer um que ilicitamente o detenha, a ideia de permitir o controle do uso das informações privativas segue lógica semelhante, dado o caráter perene do vínculo que se estabelece entre o titular e os dados extraídos (ainda que com a sua aquiescência) da sua vida privada.

Por fim, outro elemento simbólico da proteção à privacidade que remeteu à coisificação do instituto encontra-se nas exceções previstas no ordenamento ao seu caráter inviolável: assim como o absolutismo da propriedade cede diante da sua submissão à sua função social, também a privacidade sucumbe perante o que se denominou interesse público. Por certo, etimológica e juridicamente os conceitos de função social e interesse público são distintos e encerram uma série de elementos que levam a sua aplicação a trilhar caminhos divergentes, mas ambos possuem um elemento ontológico em comum, a saber, a necessária inferioridade do campo privado diante da prevalência do bem maior da coletividade. Com efeito, a "pressão do Estado para aumentar a quantidade e a qualidade de informações sobre os cidadãos, bem como para garantir a segurança e a saúde públicas" (GEDIEL e CORRÊA, 2008, p. 145), levando ao relaxamento do caráter intransponível da vida privada, pouco ou nada difere - ao menos simbolicamente - da mitigação das faculdades de usar, gozar e dispor a que se submetem os proprietários de bens que se sujeitem à desapropriação "para atender a uma necessidade ou utilidade pública, ou a um interesse social" (RODRIGUES, 2009, p. 7). Escreve-se simbolicamente porque para certo imaginário que se forma em torno dos dois valores - notadamente o imaginário da doutrina jurídica que forneceu o supedâneo ideológico para formatar as exceções ao regime de propriedade -, não costumam (ou não deveriam) causar escândalo as incursões que a autoridade política faz para, desprezando os direitos de propriedade ou de privacidade, tomar os bens ou informações privativas dos cidadãos, desde que justificadas para proteger o bem maior coletivo.

Ao contrário, a depender do contexto, ou bem as infringências ao caráter inviolável desses direitos são

e a sua privacidade está abalada. Não só vivemos um momento em que a privacidade é constantemente violada pelo 'outro', como, nós mesmo, de forma deliberada, 'submetemos à matança nossos direitos de privacidade por vontade própria'. Ser 'privado' é mal vol.12, no. 01, Rio de Janeiro, 2019.pp.423-443 
vistas como um mal necessário, ou a própria proteção a eles conferida é tida por exagerada, um luxo para proteger privilégios de quem estaria usurpando o bem comum.

\section{O SIGILO BANCÁRIO COMO ESPÉCIE DE DIREITO DA PRIVACIDADE}

O sigilo bancário, entendido como "a obrigação do banqueiro (...) de não revelar certos fatos, atos, cifras ou outras informações de que teve conhecimento por ocasião do exercício de sua atividade bancária" (ABRÃO, 2014, p. 91), é instituto jurídico vinculado ao imperativo de proteção à privacidade (SALOMÃO NETO, 2014, p. 647). A informação sobre o patrimônio que alguém detém perante uma instituição financeira é considerada um dos elementos que compóem a vida privada tutelada pelo inciso X, do artigo $5^{\circ}$, da Constituição Federal, e por isso, sujeita à cláusula de inviolabilidade, devendo ser mantida em segredo. No ordenamento brasileiro, o direito de sigilo foi positivado concomitantemente à própria regulação do sistema financeiro, realizada pela Lei no 4.595 , de 31 de dezembro de $1964^{\circ}$, o que denota a sua estreita relação com a própria elaboração legislativa do direito bancário. Assim, tem-se que o sigilo bancário é um elemento praticamente inerente à prestação de serviços bancários, e as alterações às quais ele se sujeitou estão umbilicalmente ligadas às modificações pelas quais a própria relação das instituições financeiras com as autoridades estatais passou.

A regra do artigo 38, da Lei no 4.595/64, estabelecia feição restritiva às hipóteses de quebra de sigilo bancário, segundo a qual a manutenção do segredo seria a regra, e a sua violação exceção a ser interpretada e aplicada em limitadas situações. Não por outra razão, a violação indevida do sigilo seria considerada crime, sujeitando "os responsáveis à pena de reclusão, de um a quatro anos", nos termos do $₫ 7^{\circ}$ do mesmo dispositivo. Ainda assim, a norma era pouco clara sobre quais eram essas hipóteses, e focava menos nos meios ou pressupostos para a sua quebra e mais nas instituições autorizadas a fazê-lo, a saber, o Judiciário, as Comissões Parlamentares de Inquérito e as autoridades fiscais, no âmbito de suas respectivas atividades inquisitórias ou fiscalizatórias. Bem por isso, dizia-se que o citado artigo 38 ostentaria "perfil estático" (ABRÃO, 2014, p. 104), a demandar disciplina mais dinâmica e que fosse capaz de dar mais elasticidade aos mecanismos de quebra do sigilo. Dessa forma, a despeito de a principiologia restritiva ter sido mantida pela Lei Complementar n 105, de 10 de janeiro de 2001 ("LC 105/01”), que veio a substituir o citado artigo da Lei no 4.595/64, a nova regulação teria, segundo a doutrina especializada, conferido mais maleabilidade às circunstâncias nas quais poder-se-ia realizar o levantamento ou mesmo desconsiderar a garantia de sigilo.

visto e tentar impedir que terceiros tenham acesso àquilo que consideramos de cunho estritamente pessoal é tachado, com bastante frequência, de censura." (CANCELLIER DE OLIVO e CANCELLIER DE OLIVO, 2016, pp. 8 e 9). 
Ao analisar as circunstâncias que autorizam a mitigação da inviolabilidade do sigilo bancário, encontramos as motivações adotadas pelo legislador para criar uma norma mais permissiva. Permissiva, sem dúvida, apesar de, em teoria, elencar situações pontuais, estabelecendo sistema de numerus clausus não previsto na regra anterior, que em tese daria maior segurança e previsibilidade ao cidadão, que desse modo saberia exatamente quais seriam as suas ações (ou suspeitas de ações), que permitiriam às autoridades debelar o sigilo e acessar os seus dados bancários. Acontece que o rol é taxativo apenas na aparência, já que o $\$ 4^{\circ}$ do artigo $1^{\circ}$ permite a quebra de sigilo se necessária à apuração de "qualquer ilícito", e "especialmente" os crimes que ele minuciosamente elenca em nove incisos 9 . Como se não bastasse, a praxe forense acabou estendendo as hipóteses para além do âmbito penal, tanto que é absolutamente comum e admitido que se quebre o sigilo bancário para, apurando e localizando o patrimônio mantido em segredo de titularidade de devedores, satisfazer obrigações pecuniárias em execuções judiciais com origem em questões de natureza cível, trabalhista e fiscal (normalmente via Bacen Jud).

Retomando a análise dos motivos adotados pelos autores da LC 105/01 para decretação judicial da quebra do sigilo, e fazendo-o sob a perspectiva de uma análise discursiva, verifica-se que o principal mote e fonte de discussões na seara legislativa foi o embate entre a privacidade do cidadão e a proteção do interesse público: "a quebra do sigilo bancário", escreve Nelson Abrão, "fica adstrita ao predomínio do interesse público, coletivo, que atenda aos ditames do bem comum," uma vez que o sigilo...

(...) conservando o seu aspecto tutelar individual cederia espaço à quebra, por envolver a natureza na qual o Estado teria no seu comando a manutenção da ordem e do equilibrio na participação das atividades correspondentes ao fim exclusivo da comunidade. (ABRÃO, 2014, pp. 107-108)

Um discurso pautado, portanto, sobre as bases simbólicas de uma disputa travada entre o indivíduo e o Estado, sendo aquele um potencial agente de delinquência, e este o protetor e defensor do bem comum. Essa disputa não é exatamente uma novidade porquanto, consoante exposto quando se tratou do direito constitucional à privacidade, a inviolabilidade das informações nunca foi tida por absoluta. Especificamente sobre o sigilo bancário, o ministro Francisco Rezek afirmava, em julgamento ainda pautado pelo artigo 38 da Lei no 4.595/64, que ele seria um instituto destinado a proteger "certo domínio" mas apenas "até o exato ponto onde alguma forma de interesse público reclame sua justificada prevalência"10.

\footnotetext{
${ }^{8} \mathrm{O}$ artigo 38 dessa Lei, revogado pela Lei Complementar no 105/01, previa a preservação do sigilo bancário ao dispor que "as instituições financeiras conservarão sigiilo em suas operações ativas e passivas e serviços prestados".

${ }^{9}$ São eles os crimes: "I - de terrorismo; II - de tráfico ilícito de substâncias entorpecentes ou drogas afins; III - de contrabando ou tráfico de armas, munições ou material destinado a sua produção; IV - de extorsão mediante seqüestro; $\mathrm{V}$ - contra o sistema financeiro nacional; VI - contra a Administração Pública; VII - contra a ordem tributária e a previdência social; VIII - lavagem de dinheiro ou ocultação de bens, direitos e valores; IX - praticado por organização criminosa."

${ }^{10}$ Cfr. STF, MS no 21.729-DF, Tribunal Pleno, julgado em 5/10/1995, maioria de votos.
} 
E foi precisamente no espectro simbólico da dicotomia interesse público versus interesse do particular que transitou o legislador ao regulamentar as possibilidades de mitigação do sigilo bancário. Nesse sentido, o projeto que deu lugar à LC 105/01 justificava as suas proposições sustentando que a norma proposta colocaria o sigilo bancário "a serviço da Democracia e da República e não contra estas", permitindo a "ressalva" dessa "espécie de direito à privacidade sempre que o interesse público assim o exigir ${ }^{p 11}$. Destarte, a ideia de inviolabilidade dos dados bancários é simbolicamente suplantada por uma alegoria do bem maior da coletividade, cuja tutela seria mais relevante do que uma prerrogativa que, a despeito de derivar de um direito fundamental, é apresentada como secundária ou de menor importância diante do valor maior do bem comum.

Apesar da sua apontada importância simbólica - é ele quem justifica a violação de um direito reputado inviolável - não se encontram definições normativas precisas do que seria o interesse público. Mas é justamente essa fluidez conceitual quem the assegura o status de enunciado performativo, no sentido atribuído por Pierre Bourdieu à construção retórica que permitiria - a depender do locutor e do receptor da mensagem - "agir no mundo social" (BOURDIEU, 2001, p. 111), influenciando uma percepção e assim moldando o comportamento das pessoas por meio da linguagem: a sua mera evocação torna admissível - quiçá desejável - a quebra do sigilo bancário e, tal qual uma fórmula mágica, a referência ao interesse público tem o condão de legitimar socialmente a quebra de um direito reputado inviolável. A questão que se impõe doravante é tentar delinear semanticamente qual seria, no panorama da sua judicialização, a morfologia desse interesse público.

\section{O QUE É ISTO, O INTERESSE PÚBLICO?}

A precisão terminológica não é, definitivamente, um objetivo do legislador ou dos intérpretes da norma que regulamenta a quebra do sigilo bancário, e isto não é, a nosso ver, obra do acaso. A atuação performativa do interesse público funciona melhor se o conceito se mantiver imbuído de vagueza ou dubiedade, de modo que, a tomarmos por correta a teoria foucaultiana dos usos disciplinares dos discursos, o discurso jurídico da prevalência do interesse público sobre o sigilo bancário é mais eficaz quando se permite aos enunciados que o compõem se adaptar às casuísticas que o desafiam. Não é preciso dizer o que é interesse público com clareza: a forma como regulamentada a questão, evidencia que a intenção foi franquear a delimitação do conceito de modo casuístico, maleável e adequável a cada circunstância. Aqui, é oportuno invocar Michel Foucault quando afirma a inexistência de "enunciado em geral, enunciado livre, neutro e independente" pois ele está sempre "fazendo parte de uma série ou de um conjunto, desempenhando um papel no meio de outros" (FOUCAULT, 2008, p. 136); ou seja, para

\footnotetext{
${ }^{11}$ Cfr. o Projeto de Lei Complementar no 220/1998 (convertido na LC 105/01).
} 
atingir a sua finalidade disciplinar, os discursos funcionam melhor se deixados livres para formatar as suas concatenações discursivas, circulando incognitamente entre os agentes sociais, assumindo morfologias múltiplas.

Sendo impreciso o termo interesse público, o mesmo não se pode afirmar a respeito da fenomenologia que o circunda; que o sitia. A simbologia empregada na regulamentação do sigilo bancário tem o efeito de sugerir que o bem comum estaria cercado de toda sorte de prática criminosa, de ardis e de fraudes, e é para combatê-los que se faria necessário levantar o segredo das informações financeiras. Por exemplo, nas discussões sobre o Projeto de Lei Complementar n² 220/1998, do qual resultaria a LC 105/01, o Deputado Luiz Carlos Hauly dizia refutar o uso do sigilo bancário "como biombo ou escudo para acobertar recursos oriundos de atividades, negócios, ações ou operações ilícitas, ilegais, criminosas ou de qualquer outra forma contrárias ao direito, à moral e aos bons costumes" ${ }^{\prime 2}$. O projeto tal qual proposto, visando "dotar o Estado e a sociedade de mecanismos de defesa, em todos os setores, inclusive no mercado financeiro, contra práticas nocivas ao interesse público", constituiria "mais um instrumento" de defesa a possibilitar "o permanente acompanhamento e a fiscalização das atividades de sonegadores, contrabandistas, agentes do crime organizado, traficantes e corruptos que de uma forma ou outra beneficiam a concorrência desleal no mundo dos negócios"13. Em reforço, vejam-se os dizeres de Nelson Abrão, reconhecido doutrinador em matéria de direito bancário, para quem a edição da LC 105/01 teria sido o resultado da "luta entre o Estado e os capitais impuros ou de difícil origem comprovada" (ABRÃO, 2014, p. 104), que se aproveitariam do sigilo bancário para esconder o patrimônio obtido em razão de suas ilicitudes.

Diante da narrativa composta por esses enunciados, as referências às atividades nocivas à coletividade e, principalmente, a associação do sigilo bancário a esses fenômenos - em todo caso a sua caracterização como instrumento ou mecanismo necessário à realização de práticas ilícitas - constituem um discurso que age no sentido de relacionar a proteção à privacidade dos dados bancários com a criminalidade; lê-se na doutrina que "a escalada da violência também tem servido de justificativa para incrementar os poderes estatais em matéria de segurança pública, ainda que mediante a violação da intimidade" (GEDIEL e CORRÊA, 2008, pp. 145/146). Na linha da análise discursiva proposta, tem-se de um lado os criminosos que se aproveitariam do sigilo bancário interesse privado - e, de outro, o Estado cuja missão seria localizar e condenar essas práticas, quebrando o sigilo bancário, protegendo assim o interesse público.

Como resultado do combate a esses fantasmas encontrados no imaginário que forneceu o sustento simbólico à LC 105/01, a norma oferece apenas um contorno morfológico ao interesse público: o juiz decreta a quebra do sigilo para instruir investigações de "qualquer ilícito", mas "especialmente" aqueles associados à

\footnotetext{
${ }^{12}$ Cfr. o Parecer do Deputado Luiz Carlos Hauly, da Comissão de Finanças e Tributação sobre o Projeto de Lei Complementar no 220/1998 (convertido na LC 105/01) - 6 de abril de 1999.
} 
violência do crime organizado (o terrorismo, o tráfico de drogas, o contrabando de armas e a extorsão mediante sequestro) ou que impliquem em lesão à ordem econômico-tributária (os crimes contra o patrimônio público, o sistema financeiro, a ordem tributária e previdenciária, e a lavagem de dinheiro - art. $\left.1^{\circ}, \mathbb{\$} 4^{\circ}\right)$. Parte das ações criminais arroladas - como a extorsão mediante sequestro e os crimes ligados à corrupção - figura no rol das fobias de certo segmento da sociedade brasileira, e a sua menção é o resultado de preocupação do legislador de contemplar acontecimentos bastante temidos pelo imaginário social da camada mais abastada. Um crime como o terrorismo, de outra sorte, somente pode ter a sua inclusão explicada pela determinação de organismos internacionais (encabeçados pelos Estados Unidos da América) em sufocar financeiramente os grupos reputados extremistas. Nesse sentido, novamente remetemos às lições de Nelson Abrão, para quem a relativização do sigilo bancário estaria relacionada ao crescimento do que ele chamou de "macrocriminalidade organizada, com os ares do terrorismo nefasto que assola as nações", a permitir a "colaboração contra as desconfianças geradas a partir dos ataques vivenciados em pleno século XXI" (ABRÃO, 2014, p. 91). Não é uma criminalidade qualquer: é uma "macrocriminalidade" que atua em conjunto com o "nefasto" terrorismo. O projeto de lei complementar é de 1998 (anterior, portanto, ao conhecido 11 de setembro), mas o espectro da guerra ao terror está ali, ainda que totalmente alheio à história e realidade brasileiras.

A sempre imprecisa descrição do interesse público que se sobrepõe para desprezar a inviolabilidade da vida privada é própria de cada situação à qual a sua invocação se faz necessária: o importante é que o imaginário simbólico que ela encarna e evoca sempre esteja disponível, permitindo a perpetuação de um discurso que torne aceitável a quebra do sigilo bancário. O interesse público não se define ontologicamente - ele é descrito por aquilo que ele não é, ou pelas práticas criminosas que a ele se opõem. Justamente para que o enunciado performativo implicado na sua invocação gere os efeitos esperados - isto é, legitime a quebra do sigilo bancário pelo juiz - é imprescindível que o conceito permaneça vago, sob pena de, retomando as palavras de Nelson Abrão, tornar estático o combate àqueles que se aproveitam do caráter privado das informações bancárias para cometer crimes. Ou seja, não foi somente a normatização da quebra do sigilo bancário que se tornou mais dinâmica com a edição da LC 105/01: também a própria definição do interesse público, em cujo nome são mitigados certos direitos de privacidade, passou a ser tratada de modo maleável, flexível, conforme as circunstâncias o demandassem.

Conquanto não se tenha descrito o interesse público de forma precisa nas normas que regem a quebra do sigilo bancário, a descrição dos entes competentes para realizá-la nada tem de vaga. Conforme os dizeres do $\$$ $4^{\circ}$ do art. $1^{\circ} \mathrm{da} \mathrm{LC} \mathrm{105/01,} \mathrm{somente} \mathrm{aos} \mathrm{membros} \mathrm{do} \mathrm{Poder} \mathrm{Judiciário} \mathrm{o} \mathrm{legislador} \mathrm{franqueou} \mathrm{tal} \mathrm{direito.} \mathrm{Por} \mathrm{certo}$ se permite aos organismos fiscalizadores do Poder Executivo Federal (Banco Central, Comissão de Valores

${ }^{13}$ Cfr. o Parecer do Deputado Luiz Carlos Hauly, da Comissão de Finanças e Tributação sobre o Projeto de Lei Complementar nº vol.12, no. 01, Rio de Janeiro, 2019. pp.423-443 
Mobiliários e Conselho de Controle de Atividades Financeiras - COAF), as autoridades tributárias, as Comissões Parlamentares de Inquérito e, às próprias instituições financeiras, o acesso aos dados protegidos pelo sigilo bancário; mas nestas hipóteses, não se fala em quebra do sigilo. E a distinção não é um preciosismo: para todos estes casos, o acesso ao dado é contínuo, ininterrupto, e com finalidade previamente definida (fiscalização do sistema financeiro nacional, busca de patrimônio tributável, análise cadastral dos clientes) $)^{14}$.

A quebra decretada pelos juízes, de outra sorte, se sujeita apenas e tão somente ao deferimento do pedido no bojo de um processo judicial, cujos requisitos para concessão, como a seguir será analisado, carecem de detalhamentos legislativos, repousando integralmente em uma confiança no bom senso dos julgadores e da figura quase mítica que eles encarnam no bojo do discurso ora analisado.

\section{O GUARDIÃO DO INTERESSE PÚBLICO}

Diferentemente do legislador europeu, que se preocupou em minuciosamente descrever as hipóteses legais de mitigação do caráter inviolável dos direitos fundamentais de privacidade (RUARO e LIMBERGER, 2011, p. 56), no sistema brasileiro esta tarefa foi delegada ao ente judicante, a quem compete realizar a análise no caso-a-caso, observando uma principiologia aplicável a esses direitos, em tudo pertinente ao regime de quebra do sigilo bancário (Idem, p. 57). Não se trata de obra do acaso: a delegação desse amplo poder ao juiz, sem mecanismos de controle, contrapesos, ou ainda penalidades em casos de abusos, lastreada exclusivamente em uma pressuposta imagem simbólica do magistrado, está inserida em um contexto discursivo bem específico; um contexto que se relaciona a certa fenomenologia de que se revestiu a atividade jurisdicional.

São eventos ocorridos no plano simbólico (eventos-símbolo) que, revestindo a figura do juiz de determinadas qualidades, conferiram-lhe competências decisórias afeitas - numa leitura, diga-se, mais clássica do constitucionalismo e da teoria da separação dos poderes - ao plano legislativo e, por via de consequência, despersonalizadas. Explica-se: se um critério está "objetivamente" previsto em lei, a sua aplicação ficaria despersonalizada, no sentido de que o ato decorreria de vontade alheia, externa, às razões adotadas pelo seu aplicador. O juiz apenas avaliaria se seria, ou não, o caso de aplicar certo comando (contido na lei, e não na decisão judicial) a determinado caso concreto. Mas em ambiente no qual as hipóteses são livres ou abertas, é o juízo do aplicador quem vai delinear os limites do comando. E, neste caso, a decisão estará imbuída de carga muito maior

220/1998 (convertido na LC 105/01) - 6 de abril de 1999.

${ }^{14}$ Vale mencionar o recente julgamento do Supremo Tribunal Federal sobre a constitucionalidade dos artigos da LC 105/01 que permitem à Receita Federal ter acesso a dados bancários dos contribuintes (ADIs n. 2390/DF, 2386/DF, 2397/DF e 2859/DF). Por 9 votos a 2, decidiu-se não se tratar de "violação" mas de mera "transferência" deste, de um ente obrigado a preservar o sigilo (Instituição Financeira) para outro (Autoridade Fiscal), de modo que se estaria diante de uma "afirmação" do direito à intimidade. 
de subjetividade e personalismo.

A hipótese que se extrai é justamente a de que certos eventos-símbolo conduziram a uma personalização da autoridade política, a qual será - para ficar no tema do presente estudo - observada à luz dos questionamentos a respeito do sigilo bancário. Vale dizer: ao procurar as respostas, no plano simbólico-discursivo, para a questão sobre as razões pelas quais se apontou o juiz como entidade-pessoa competente para definir as hipóteses de quebra de sigilo bancário (diferentemente de outros sistemas, como o europeu, que mantiveram no legislador tal prerrogativa), vai-se percorrer uma série de enunciados que conduzem à elaboração e propagação de um discurso que resulta na personificação da legitimação de certos atos de poder.

O primeiro desses eventos-símbolo a que se fará referência é encontrado no universo de manifestações a respeito de um pretenso atributo dos juízes que lhes outorgaria a legitimidade para dizer o direito - "jurisdição", do latim "juris dictio", "dizer o direito" -, inclusive, no que aqui interessa, a decretação da quebra de sigilo bancário. Trata-se do chamado princípio da imparcialidade do juiz, "inseparável do órgão da jurisdição", segundo o qual "o juiz coloca-se entre as partes e acima delas", tratando-se de "pressuposto para que a relação processual se instaure validamente" (CINTRA, GRINOVER e DINAMARCO, 2000, pp. 51-52). Apontada como "um dos dogmas das democracias contemporâneas" (BARROSO, 2012, pp. 18-19), a imparcialidade (ou independência) do juiz seria um pressuposto da atuação do juiz, praticamente inerente ao seu ofício de aplicador da lei. Tamanha a ênfase com a qual é posta a questão da independência do magistrado em relação às partes litigantes, que ela é colocada em um patamar de mito inquestionável, levando, por exemplo, um ministro do Supremo Tribunal Federal a se referir ao Poder Judiciário como "órgão absolutamente equidistante"15.

No plano normativo, a tal imparcialidade assentaria em uma série de garantias constitucionalmente previstas para proteger o magistrado de pressões externas - as garantias da "inamovibilidade, vitaliciedade e irredutibilidade de subsídios" (CF, art. 95), as vedações ao desempenho de certas atividades (CF, art. 95, parágrafo único) e a proibição de tribunais de exceção (CF. art. 5\% inc. XXXVII), agiriam como avalistas de uma atuação independente e firme, alheia às influências de cunho econômico, midiático ou político. São marcantes, a propósito e por demonstrarem o caráter absoluto da autoproclamada imparcialidade dos juízes, a qual estaria a salvo até mesmo de influências ideológicas (contrariando o conhecido aforismo de Aristóteles, que dizia ser o homem um "animal político"), as palavras do também Ministro do Supremo Tribunal Federal Luís Roberto Barroso, para quem "juízes são independentes da política e limitam-se a aplicar o direito vigente, de acordo com critérios aceitos pela comunidade jurídica" (BARROSO, 2012, p. 18). Inclusive, para se ter uma ideia da importância da imparcialidade do juiz na retórica (discurso) jurídica, à guisa de justificar tais garantias, a sua independência é

${ }^{15}$ Cfr. o voto do ministro Marco Aurélio no RE no 461.366/DF, Primeira Turma, julgado em 3/8/07, maioria de votos. vol.12, no. 01, Rio de Janeiro, 2019.pp.423-443 
apresentada como "mais importante para a eficácia dos direitos fundamentais do que o próprio catalogo de direitos contido nas Constituições" (MENDES e STRECK, 2013, p. 1.329); por outras palavras, na visão desta linha doutrinária, mais importante do que prever direitos fundamentais em diplomas legais, seria necessária a intervenção de um magistrado efetivamente imparcial para vê-los efetivados.

E o efeito dessa retórica faz-se marcantemente presente na questão do sigilo bancário: nas discussões parlamentares sobre o projeto de lei que daria lugar à LC 105/01, cogitou-se atribuir aos membros do ministério público a competência para decretar a quebra do sigilo bancário. A resposta por parte do Deputado Federal Ney Lopes foi enfática e negativa:

Em que pese ser o Ministério Público, órgão constitucionalmente incumbido de fiscalizar a lei, e o Tribunal de Contas da União, órgão auxiliar do Poder Legislativo no controle externo, somente com a intervenção do Judiciário, no curso de um processo ou de um inquérito, será garantido o exercício do contraditório e da ampla defesa àqueles que tivessem o seu sigilo ameaçado $^{16}$.

O simbolismo imiscuído nestas poucas palavras é bastante ilustrativo. O ministério público, apesar de órgão estatal, é parte, é litigante; o juiz, também membro do Estado, não. Ele é o terceiro, equidistante, imparcial, desinteressado, preocupado apenas em equilibrar o interesse público que combate o crime com os direitos fundamentais dos cidadãos. Apesar da sua assertividade, o raciocínio mostra-se circular: a despeito de integrar o Estado como um de seus Poderes, o Judiciário seria um terceiro independente (imparcial), e a ele caberia avaliar e, se for o caso, repelir ações dos agentes estatais, inclusive em relação à violação de sigilo bancário. Agiria, pois, como "expressivo instrumento de proteção das pessoas em geral contra as ações eventualmente arbitrárias do Poder Público, qualquer que seja a dimensão institucional em que se projete a atividade estatal"17 Uma (pres)suposição absoluta, incisiva.

E o ponto aqui não é determinar se o juiz é capaz ou não de ser imparcial, mas questionar o que permite a assunção desta premissa sem que ela tenha sido sequer desafiada. É exatamente isso que o discurso sob análise permite: criar as condições simbólicas, incutindo no senso comum dos juristas a imagem pré-formatada da isonomia do juiz, a ponto de tê-la por verdade indiscutível. Não obstante a ausência de rigor lógico-factual na construção retórica, é a partir deste arcabouço discursivo que se afirma, como o fez um ministro do Supremo Tribunal Federal em certa ocasião, que "somente o Poder Judiciário poderia decretar a quebra do sigilo bancário," porquanto seus membros agiriam "com cautela, com prudência, com moderação," já que estas seriam "as virtudes inerentes à magistratura, ou virtudes que os magistrados devem possuir ${ }^{18}$. Mais do que um dever de

${ }^{16}$ Cfr. o Parecer do Deputado Ney Lopes, da Comissão de Constituição e Justiça Tributação sobre o Projeto de Lei Complementar no 220/1998 (convertido na LC 105/01) - 10 de fevereiro de 2000.

${ }^{17}$ Cfr. STF, MS no 23.452/RJ, Rel. Min. Celso de Mello, Tribunal Pleno, julgado em 16/9/99, v.u.

${ }^{18}$ Cfr. o voto do ministro Carlos Velloso no MS no 21.729-4/DF, Tribunal Pleno, julgado em 5/10/95, maioria de votos. Em reforço, vejamos como prossegue a argumentação do ministro: "Não posso admitir que a parte, que não tem o dever ou a obrigação 
imparcialidade: são virtudes (cautela, prudência, moderação), inerentes (não dependem da pessoa, mas do cargo que ocupam), atribuídas aos juízes por um juiz (de Suprema Corte, por certo), em uma construção metalinguística autorreferente.

Para além da discussão a respeito do caráter performativo desses enunciados, tem-se que essa mitologia da imparcialidade produz uma espécie de isolamento simbólico do magistrado do meio no qual atua - o conflito jurídico - como que o posicionando em patamar diferenciado em relação às partes litigantes. E é desse plano que the é reservado que o juiz, agindo como guardião do interesse público e seguindo critérios e virtudes que seriam inerentes à autoridade que a sua figura representa, decide sobre a existência de interesse público apto a determinar a quebra do sigilo bancário, daí a se falar em personificação do ato da autoridade (qual seja, o ato de autoridade que mitiga um direito declarado inviolável). Mais, quando tomadas em conjunto, as repetidas afirmações formam uma amálgama discursiva de inequívoco "uso fabulador" (WARAT, 1995), que criam e moldam a imparcialidade em plano unicamente abstrato. Mas, é sobre ele, a despeito de encontrar lastro apenas nessa carga imaginativa da retórica jurídica, que se apoia a irrestrita confiança na figura do juiz.

Por outros termos, ele é imparcial, porque assim o dizem os princípios. Assim o asseguram as garantias constitucionais. Assim o confirmam as decisões judiciais (em um exercício de metalinguagem). Assim o assevera a doutrina. Enfim, assim o anunciam os cânones jurídicos, a despeito de essa (importante) afirmação jamais ser testada ou questionada efetivamente.

Outro evento-símbolo particularmente relevante no contexto proposto neste artigo, até certo ponto relacionado à imparcialidade do juiz, é a submissão (cada vez mais comum) de temas usualmente debatidos em âmbito político, ao crivo de uma deliberação tomada no ambiente jurisdicional, o que veio a se chamar de ativismo do Judiciário, entendido como "[...] participação mais ampla e intensa do Judiciário na concretização dos valores e fins constitucionais, com maior interferência no espaço de atuação dos outros dois Poderes" (BARROSO, 2012, p.9).

O fenômeno de reconhecer-se na pessoa do magistrado a capacidade de decidir tais assuntos não é recente, embora suas consequências talvez sejam mais perceptíveis atualmente, principalmente pela dimensão que o fenômeno vem tomando, inclusive devido à sua reverberação nos meios de comunicação. No processo judicial - o habitat natural do juiz -, é notável o destacado papel atribuído a ele pelas leis processuais brasileiras, com o respaldo e supedâneo da doutrina jurídica que contribuiu decisivamente para a sua elaboração desde pelos menos os anos 70, do séc. XX (OLIVEIRA, 2015): o livre convencimento, a função pacificadora da jurisdição, a

de ser imparcial, e que há de ser parcial, porque é inerente à parte ser parcial, não posso admitir que possa ela própria, por suas próprias mãos, efetivar a quebra de um direito inerente à privacidade, que a Constituição consagra, que tem, portanto, 'status' constitucional". 
instrumentalidade das formas, a distribuição dinâmica do ônus probatório, a existência de jurisprudência defensiva, a busca da verdade real, são fórmulas discursivas que franqueiam ao juiz atuar com elevado grau de subjetivismo e voluntarismo. Permitem ao julgador moldar o rito e os atos processuais, paradoxalmente construídos sobre bases essencialmente garantistas, a interesses episódicos, sem a justificação das escolhas tomadas, controle (a não ser de seus pares, pelas vias recursais), ou mesmo punições aos abusos. Para além do campo processual, é possível perceber que em diversas normas foram inseridas regras abertas com lacunas a serem preenchidas pelo juiz, no momento de sua aplicação, conferindo à tutela jurisdicional o senso de parâmetro de condutas ou comportamentos, seja no âmbito das normas infraconstitucionais ou mesmo constitucionais ${ }^{19}$.

Todo esse cenário se deve em grande parte à implementação prática de certos conceitos moldados de acordo com o discurso segundo o qual o juiz, por ser o representante da autoridade estatal, agiria na qualidade de garantidor da manutenção da ordem (interesse) pública, daí a sua ascendência sobre as partes na dinâmica processual e fora dela (STRECK, 2013, pp. 75 e 76). Longe de ser fruto do acaso, nem muito menos de uma espécie de usurpação por parte dos quadros da magistratura, essa competência decisória foi delegada aos juízes pelo próprio legislador, em um movimento de alijamento deliberado (TAVARES, 2012, p. 24), permitido, em grande parte, pelo verniz discursivo de que se revestiu a atividade jurisdicional perante o imaginário coletivo.

Ao explorar os elementos simbólicos de que foram acobertados os magistrados na construção deste discurso ativista, o que chama mais a atenção foi a edificação simbólica de uma imagem de instituição judiciária que, além de imparcial, exerceria papel contramajoritário, reputado imprescindível para a garantia de direitos fundamentais e do próprio sistema democrático - interesse público, pois (PINTO e DONADELLI, 2014, pp. 75 e 76). A base desse edifício retórico encontra-se na doutrina constitucionalista mais recente que, inspirada nas lições de juristas estrangeiros, alterou o modo de atuação do Poder Judiciário, no bojo da sua relação com os demais Poderes. Assim, seja pela vertente neconstitucionalista, ou mesmo pelo viés da chamada jurisdição constitucional, a ideia de permitir, ou melhor, estimular decisões judiciais com base em princípios ou cláusulas abertas, denota confiança cega na capacidade, razoabilidade e discernimento dos membros do Judiciário - fala-se até em "culto ao Poder Judiciário" (BOLONHA, RANGEL e ALMEIDA, 2014, p. 68) -, como se se tratasse de um órgão composto de figuras melhor capacitadas a deliberar sobre o bem comum, muitas vezes em sentido contrário ao decidido em âmbito parlamentar. Aqui, remete-se o leitor à doutrina internacional, notadamente do juiz Antoine Garapon (GARAPON, 1999) que, ao tratar da crescente atuação do Judiciário em questões políticas,

\footnotetext{
${ }^{19}$ No Código Civil, é ao magistrado que caberá, "a seu critério", fixar valores de alugueres (art. 572), nomear administrador provisório a pessoas jurídicas (art. 49), determinar o valor de indenizações (arts. 944 e ss), ou mesmo confirmar a validade de testamentos particulares (arts. 1.878 e 1.879). A Constituição Federal foi emendada para incluir uma miríade de competências normativas ao Judiciário, destacando-se a reforma entabulada pela Emenda Constitucional no 45/04, que consagrou o sistema de súmulas vinculantes. A propósito, conferir TAVARES, 2012, pp.23-24.
} 
conferiu aos juízes o relevante papel de ser o "guardião das promessas" de um sistema democrático desgastado, desligado das demandas contemporâneas da cidadania.

Com base nesses enunciados discursivos, a delegação da competência decisória aos juízes para que eles, definindo os limites e características do interesse público, determinem medidas que suplantem a cláusula de inviolabilidade que recai sobre o sigilo bancário, mostra-se aceitável, quiçá desejável. Por que, diante dessa figura imparcial, forte e autossuficiente, duvidar de sua capacidade de avaliar a conveniência de devassar o patrimônio dos cidadãos, sobretudo se estiver em jogo o interesse da coletividade, a quem ele tão bem tutela? Mais uma vez, está-se diante de uma formulação apriorística, não testada ou sujeita a questionamentos objetivos, o que se deve em boa parte à própria forma como são constituídos os argumentos das correntes doutrinárias adeptas da chamada jurisdição constitucional, a despeito de severos problemas epistemológicos (BOLONHA, RANGEL e ALMEIDA, 2014, p. 73).

Assim, tem-se que o fenômeno do ativismo do Judiciário, visto sob as lentes da fixação dos critérios de quebra de sigilo bancário, apresenta-se como um movimento de migração do foco de legitimação dos atos de autoridade do campo democrático-representativo, representado pelo Parlamento-legislador que definiria os critérios com base na chamada vontade da maioria, para a seara das decisões jurisdicionais, que se lastreiam em interpretações episódicas do abrangente e praticamente ilimitado texto legal, a serem realizadas pela pessoa do julgador.

Por fim, ainda na linha de explorar a personificação do ato de decidir sobre a violação dos dados bancários, verifica-se que a apreciação da decisão jurisdicional é feita interna corporis, ou seja, são os próprios membros do Judiciário que avaliarão, se provocados e por meio de recurso, sobre a conveniência ou viabilidade de quebra do sigilo bancário. Eventual reconhecimento em grau recursal de que a decisão de quebra não observou o interesse público não terá efeitos práticos ou reparatórios: se o sigilo foi quebrado, ainda que ilegalmente, não há como se retornar ao status quo ante, mas também não se pode obter o ressarcimento de quem a decretou, dado que a pessoa do magistrado só responde por danos em casos de "dolo ou fraude" (CPC, art. 143, inc. I). Assim é que a violação a um direito fundamental, descrita como crime pela LC 105/01 (arts. 10 e 11), é reduzida a mero erro de interpretação, a ser avaliada entre pares em sede recursal, sem maiores consequências para o agente causador do prejuízo.

\section{CONSIDERAÇÕES FINAIS}

O objetivo deste estudo foi analisar os discursos que atuam na fundamentação política da atuação dos juízes na contemporaneidade, a partir da descrição da simbologia de que se reveste o direito à privacidade, sob os 
auspícios do sigilo bancário e das hipóteses legalmente admitidas para sua quebra.

Conclui-se que, muito longe de ser a esfera intransponível sugerida por parte da dogmática constitucional, os dados e informações que o sigilo bancário pretende proteger constituem um patrimônio sujeito à expropriação, se assim o necessitar o interesse público. Um interesse público direcionado pela lei, com olhos voltados para um objetivo: a luta contra o ilícito, o uso abusivo dos privilégios do sigilo bancário para se ver a salvo dos organismos fiscalizadores e, no extremo, a prática de crimes que desafiam o bem comum.

Assim, o sigilo bancário mantém-se sob permanente ameaça de quebra. A bem dizer, na narrativa à qual este estudo se dedicou, é como se ele só existisse simbolicamente, em razão da possibilidade de vir a ser violado. Como se o reconhecimento da sua inviolabilidade só ocorresse a partir do momento em que as razões para a sua mitigação seriam evidenciadas. Descrito a priori como um bem pertencente ao cidadão, o direito à privacidade acaba por se converter em um dos elementos a compor o jogo de gato e rato do qual o desafiador do interesse público invariavelmente sairá vencido. Em outros termos, ele é o obstáculo colocado perante a autoridade estatal justamente como desafio à sua sublimidade, para que ela possa, por meio de seus agentes, expressar a sua superioridade soberana. Uma vez quebrado o sigilo, o indivíduo está exposto, prostrado, submisso, e pouco tem a fazer, a não ser sujeitar-se a esta potência irreversível, que pode ainda se desdobrar, impondo outras restrições (notadamente patrimoniais, no caso de uma penhora ou bloqueio de bens). No bojo desta narrativa, uma figura se destaca como responsável pela tutela do interesse público: na ausência de clara delimitação legal do conceito, o juiz se apresenta como aquele capaz de - isolada e pessoalmente - atribuir contornos ao bem comum, seguindo critérios de conveniência e oportunidade por ele mesmo fixados.

Destarte, muito longe de defender a atribuição de um caráter absoluto ao sigilo bancário, ou mesmo enrijecer a sua proteção, o ponto central da presente reflexão é justamente este: a anunciação da inviolabilidade do direito ao sigilo bancário funciona simbolicamente como pretexto para consagrar a autoridade soberana personificada na figura do juiz, a quem se conferiu a competência para quebrá-lo.

Conforme se procurou demonstrar, a atribuição desta prerrogativa aos magistrados está relacionada a uma série de acontecimentos ocorridos no plano simbólico (eventos-símbolo), que lhes impingiram certas características e atributos diferenciados, no âmbito de uma mitologia da atividade jurisdicional. Dentre esses eventos-símbolo, destaca-se o reconhecimento apriorístico de virtudes como a imparcialidade, cautela, prudência, comedimento, além da atribuição de competência decisória para resolver dilemas morais ou políticos, no âmbito do que se convencionou denominar ativismo do Judiciário. Enfim, qualidades e responsabilidades que já não mais seriam associadas ao legislador, a tomar por corretas as premissas dos enunciados discursivos analisados.

Enunciados estes que lograram constituir uma imagem simbólica da pessoa do juiz perante certo imaginário coletivo - em todo caso perante o imaginário de parte considerável da doutrina e da jurisprudência - 
suficientemente sólida para confiar-lhe plenamente a tarefa de guardar e proteger o interesse público, ainda que diante de um bem jurídico reputado fundamental, a saber, a privacidade sob os auspícios do sigilo bancário. De fato, se, para certa visão doutrinária, especialmente a neoconstitucionalista, aos juízes teria sido conferido mandato para atuar de modo contramajoritário, assegurando o exercício de direitos fundamentais às minorias, então seria quase tautológica, a se tomar por realidade a roupagem simbólica, a conclusão de que também eles estariam habilitados a verificar a viabilidade de mitigar a inviolabilidade do sigilo bancário. Com efeito, essa leitura mostrase absolutamente alinhada à metodologia sugerida pela LC 105/01 quando trata das hipóteses de quebra de sigilo bancário pelo juiz: a fixação do critério e a avaliação da conveniência de violar a privacidade do cidadão são totalmente delegados ao magistrado que, na ausência de parâmetros mínimos - os incisos indicados no $₫ 4^{\circ}$ do art. $1^{\circ}$ são quase ilustrativos - decidirá com base em valorações pessoais, quando não morais, ou meramente pragmáticas.

Assim, tem-se que o discurso pelo qual aqui se transitou logrou deslocar a autoridade moral de deliberar e decidir sobre os critérios definidores do interesse público do campo dos debates legislativos para a seara jurisdicional, especialmente sob os auspícios de leituras morais da lei, realizadas com fundamento em interpretações amplas do texto constitucional.

As correntes neoconstitucionalista e da jurisdição constitucional tiveram papel relevante neste desenho simbólico, mas talvez tenham agido muito mais como catalisadores de uma tendência, do que como seus protagonistas. Com efeito, os questionamentos epistemológicos feitos a essas vertentes - notadamente de se basearem em presunções e conclusões apriorísticas, de se lastrearem em afirmações nunca ou pobremente testadas na realidade (fabuladoras, pois) - podem ser formulados também quando se debruça sobre os enunciados que, à guisa de justificar a competência do Poder Judiciário para avaliar a viabilidade de decretar a quebra de sigilo bancário, atribuem virtudes sobre-humanas à pessoa dos juízes. Para este imaginário simbólico, ao invés do legislador cujas decisões são legitimadas pela vontade da maioria, é o magistrado - e somente ele - quem, com base em virtudes simbolicamente inerentes ao seu cargo, vai avaliar e determinar os critérios de mitigação de um direito fundamental.

BANK SECRECY: THE JUDGE AND THE PROTECTION OF CITIZEN'S PRIVACY WITHIN THE INFORMATION SOCIETY

\section{Abstract}


The theme is the breach of bank secrecy in the Brazilian judicial procedure. The objective is to critically analyze the main arguments that sustain the mitigation, performed by the judges, of one of the aspects of the fundamental right to privacy, taken as inviolable by the constitutional mainframe. The method is the discourse analysis, inspired by Foucault's philosophy, performing a "genealogy" of doctrine, jurisprudence and legal speeches, related to this inviolability and the attributes conferred in the symbolic field upon judges, through the personification of the decision act, sustained, without any criticism, on supposed virtues of the judges. It concludes that the analyzed speeches, besides resulting objectively on the lack of controls on the decision basis, establishes a disciplinary relationship that sublimes the judge figure, turning it into a singularized incarnation of the State authority, with potential prejudices to the citizen fundamental guarantees.

Keywords: privacy - bank secrecy - public interest - jurisdiction - speeches analysis.

\section{REFERENCIAS DAS FONTES CITADAS}

ABRÃO, Nelson. Direito Bancário. 15ª ed. São Paulo: Saraiva. 2014

BARROSO, Luis Roberto. Constituição, democracia e supremacia judicial: direito e política no Brasil contemporâneo. Revista da Faculdade de Direito- UERJ. Vol. 2, no 21, Janeiro/Junho. 2012, s/p.

BOLONHA, Carlos, RANGEL, Henrique e ALMEIDA, Maíra. Críticas sistêmicas aos estudos constitucionais brasileiros. Revista da Faculdade de Direito - UFPR. Vol. 59, no 1, 2014, p. 53-78

BOURDIEU. Pierre. Langage et pouvoir symbolique. Paris: Seuil. 2001

CANCELLIER DE OLIVO, Luis Carlos e CANCELliER DE OLIVO, Mikhail Vieira. Intimamente publicitados: o Direito à privacidade das celebridades na sociedade contemporânea. Novos Estudos Jurídicos. Vol. 21, nº 1, Jan.-Abril, 2016, p. 6-30

CINTRA, Antonio Carlos de Araújo. GRINOVER, Ada Pellegrini e DINAMARCO, Cândido Rangel. Teoria Geral do Processo. 16ª ed. São Paulo: Malheiros. 2000 
FOUCAULT, Michel. L’ordre du discours. Paris: Gallimard. 1971

Il faut défendre la société - Cours au Collège de France. 1976. Paris: Gallimard. 1997

L’Archéologie du savoir. Paris: Gallimard. 2008.

GARAPON. Antoine. O juiz e a democracia: o guardião das promessas. Rio de Janeiro: Revan. 1999

GEDIEL, José Antônio Peres e CORRÊA, Adriana Espíndola. Proteção jurídica de dados pessoais: a intimidade sitiada entre o Estado e o mercado. Revista da Faculdade de Direito - UFPR. Vol. 47, 2008, p. 141-153

MENDES, Gilmar e STRECK, Lenio Luiz. Comentários ao artigo 95. in CANOTILHO, J. J. Gomes; MENDES, Gilmar F.; SARLET, Ingo W.; STRECK, Lenio L. (Coords.). Comentários à Constituição do Brasil. São Paulo: Saraiva/Almedina. 2013, p. 1.329-1.331

OLIVEIRA, Bruno Batista da Costa. Jurisdição e Poder: usos disciplinares dos discursos do processo civil. Curitiba: Juruá. 2015.

PINTO, Felipe Chiarello de Souza e DONADELLI, Antonio Paulo de Mattos. O papel do Judiciário, o Estado de Direito e o chamado "ativismo judicial" na doutrina brasileira. Novos Estudos Jurídicos. Vol. 19, no 1, Jan.-Abril, 2014, p. $42-76$

RODRIGUES, Silvio. Direito Civil - Vol. 5 Direito das Coisas. 28a ed. São Paulo: Saraiva. 2009

RUARO, Regina Linden e LIMBERGER, Têmis. Administração pública e novas tecnologias: o embate entre o público e o privado - análise da Resolução 121/2010 do CNJ. Novos Estudos Jurídicos. Vol. 16, no 2, MaioAgosto 2011, p. 121-134

RUARO, Regina Linden, RODRIGUEZ, Daniel Piñeiro e FINGE, Brunize. O Direito à proteção de dados pessoais e a privacidade. Revista da Faculdade de Direito - UFPR. Vol. 53, 2011, p. 45-66

SALOMÃO NETO, Eduardo. Direito Bancário. 2a ed. São Paulo: Atlas. 2014 
SAMPAIO, José Adércio Leite. Comentários ao artigo 5, inciso X. in CANOTILHO, J. J. Gomes; MENDES, Gilmar F.; SARLET, Ingo W.; STRECK, Lenio L. (Coords.). Comentários à Constituição do Brasil. São Paulo: Saraiva/Almedina. 2013, p. 276-285

SCKELL, Soraya Nour. Os juristas e o direito em Bourdieu - A confituosa construção histórica da racionalidade jurídica. Tempo Social, revista de sociologia da USP. v.28, n. 1, abril 2016, p. 157-178.

STRECK, Lenio Luiz. Hermenêutica e Princípios da Interpretação Constitucional. in CANOTILHO, J. J. Gomes; MENDES, Gilmar F.; SARLET, Ingo W.; STRECK, Lenio L. (Coords.). Comentários à Constituição do Brasil. São Paulo: Saraiva/Almedina. 2013. p. 75-90

TAVARES, André Ramos. Paradigmas do Judicialismo Constitucional. São Paulo: Saraiva. 2012, p. 75-91

WARAT, Luis Alberto. O direito e sua linguagem. 2a ed. Porto Alegre: Sérgio Antonio Fabris. 1995.

Trabalho enviado em 11 de novembro de 2017

Aceito em 12 de janeiro de 2019 